\title{
ETHICS AND MODERN BUSINESS
}

\author{
BY \\ HENRY S. DENNISON
}

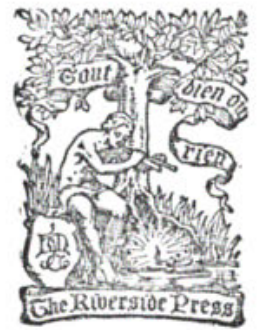

BOSTON AND NEW YORK

HOUGHTON MIFFLIN COMPANY

Ebe Riberside Press Cambrioge

I932 
COPYRIGHT, 1932, BY THE REGENTS OE TER

UNIVERSITY OF CALIFORNTA

ALL RIGHTS RESERVED INCLUDING THE RIGHT TO REPRODUCE THIS BOOK OR PARTS THEREOF IN ANY FORM

The Rotbetsibe Press

CAMBRIDGE - MASSACHUSETTS

PRINTED IN THE U.S.A. 


\section{BARBARA WEINSTOCK LECTURES ON THE MORALS OF TRADE}

This series will contain essays by representative scholars and men of affairs dealing with the various phases of the moral law in its bearing on business life under the new economic order, first delivered at the University of California on the Weinstock Foundation. 
